This is a pre-copyedited, author-produced PDF of an article accepted for publication in ICSID ReviewForeign Investment Law Journal following peer review. The version of record M Paparinskis, 'Circumstances Precluding Wrongfulness in International Investment Law' ICSID ReviewForeign Investment Law Journal is available online at: $x \times x \times x \times x$.

\title{
Circumstances Precluding Wrongfulness in International Investment Law
}

\author{
Martins Paparinskis*
}

\section{Introduction}

To address issues of State responsibility before international investment arbitration tribunals from the perspective of circumstances precluding wrongfulness seems odd. In investment treaty claims the common practice, in line with the position taken in international dispute settlement more generally, ${ }^{1}$ is to first deal with attribution and breach as the two necessary criteria of State responsibility. ${ }^{2}$ If State responsibility does arise, the common practice, again in line with the position taken in international law more generally, ${ }^{3}$ is to consider content of responsibility and reparations. ${ }^{4}$ Circumstances precluding wrongfulness may, of course, play an important role in particular disputes. But their systemic role, both in international investment law and more generally, is neither central nor, at least in the form in which they are expressed in contemporary international law, likely to be of great practical importance. To adopt them for an analytical perspective is, one might think, akin to performing Hamlet without the Prince of Denmark. Still, the decision to omit the main hero and approach the issue through the eyes of secondary characters may be justified, ${ }^{5}$ at least if casts new light on a well-known story.

The examination of international investment law through the lens of circumstances precluding wrongfulness will be undertaken in three parts. The first will briefly sketch the background and identify materials relevant for analysis (Section II). The second part will address

\footnotetext{
* Lecturer, Faculty of Laws, University College London, London, United Kingdom. Email:m.paparinskis@ucl.ac.uk. I am grateful to Anastasios Gourgourinis, Jean Ho, John Marjason-Stamp, Cameron Miles, Federica Paddeu, Ira Ryk-Lakhman, and two anonymous reviewers for their comments on the draft paper. The usual caveat applies.

${ }^{1}$ Netherlands v Russia, PCA Case no 2014-02, Award on the Merits, 14 August 2015 [200]-[201]; 2001 ILC Articles on State responsibility for internationally wrongful acts <http://legal.un.org/docs/?path=../ilc/texts/instruments/english/draft_articles/9_6_2001.pdf\&lang=EF> art 2. 2 Adel al Hamadi al Tamimi v Oman, ICSID Case no ARB/11/33, Award, 3 November 2015 [314]-[468].

${ }^{3}$ Certain Activities Carried out by Nicaragua in the Border Area (Costa Rica v Nicaragua), Construction of a Road in Costa Rica along the San Juan River (Nicaragua v Costa Rica) [2015] ICJ Rep <http://www.icj-cij.org/docket/files/152/18848.pdf> [138]-[142], [224]-[228]; 2001 ILC Articles (n 1) Part Two.

${ }^{4}$ Quiborax SA and Non Metallic Minerals SA v Bolivia, ICSID Case no ARB/06/2, Award, 16 September 2015 [307].

5 Rosencrantz \& Guildenstern are Dead (1990) <http://www.imdb.com/title/tt0100519/>; M de Grazia, 'Hamlet' without Hamlet (CUP 2007).
} 
in turn four circumstances precluding wrongfulness, in the order in which they appear in the 2001 ILC Articles on State responsibility for internationally wrongful acts ('2001 ILC Articles'): consent (Section III), self-defence (Section IV), countermeasures (Section V), and necessity (Section VI). ${ }^{6}$ The final section will consider the question of compensation when circumstances precluding wrongfulness apply (Section VII). This article does not purport to provide an exhaustive examination of practice and decisions on the issue, ${ }^{7}$ focusing instead on selected issues of importance.

This article resists the temptation to make a sweeping broader point, instead advancing two propositions that, while narrower in scope, directly touch upon the systemic pulse of international investment law and law of State responsibility. For international investment law, decisions addressing circumstances precluding wrongfulness provide an excellent illustration for how blackletter international law works. The distinctions between primary and secondary rules, treaty law and customary law, and nature of rights and obligations inform the legal architecture, within which application of law to particular facts in light of particular procedural choices takes place. Unsurprisingly circumstances precluding wrongfulness, while providing one important ingredient to the argument, will rarely be decisive on their own. For law of State responsibility more generally, developments in international investment law show little systemic coherence of circumstances precluding wrongfulness as a category, either regarding individual circumstances or cross-cutting rules. Back in 1999, Vaughan Lowe expressed doubts about the value of collating within the confines of a single category rules that are so diverse, both in terms of technical drafting and underlying policies. ${ }^{8}$ The practice of investment law confirms the prescience of those concerns.

\section{Works and Days}

\footnotetext{
${ }^{6}$ I will not address distress and force majeure. Distress as a circumstance precluding wrongfulness, 2001 ILC Articles (n 1) art 24, does not appear to have played a role in international investment law (although it is conceivable that circumstances relating to danger to human life could be invoked to justify the choice by States to breach primary obligations, analogously to the claim of necessity). Force majeure as a circumstance precluding wrongfulness, (n 1) art 23 , has been invoked a number of times. But its discussion would not go beyond a pedantic reminder that a rule of domestic law is not the same thing as a rule of international law, even if they share the same name, and even if the former has at some point contributed to the creation of the latter, through the crucible of general principles in foro domestico, F Paddeu, 'A Genealogy of Force Majeure in International Law' (2011) 82 BYBIL 381. Conflating both rules is at the very least aesthetically displeasing, and may constitute an error of law, see Autopista Concesionada de Venezuela CA v Venezuela, ICSID Case no ARB/00/5, Award, 23 September 2003 [108]; Sempra Energy International v Argentina, ICSID Case no ARB/02/16, Award, 28 September 2007 [246] (annulled, but not for this reason).

7 See C Binder, 'Circumstances Precluding Wrongfulness' in M Bungenberg and others (eds), International Investment Law: A Handbook (CH Beck/Hart/Nomos 2015).

${ }^{8}$ V Lowe, 'Precluding Wrongfulness or Responsibility: A Plea for Excuses' (1999) 10 EJIL 405.
} 
The intellectual landscape of the contemporary law of State responsibility is dominated by the framework and language of the 2001 ILC Articles, particularly the distinction drawn there between primary obligations and secondary rules of State responsibility. That has not always been the case. Several influential drafts and writings of the first half of the last century addressed together what would now be dealt with separately: secondary rules of State responsibility and primary rules on the protection of aliens and investors. ${ }^{9}$ For a contemporary reader perusing these materials, the challenge lies in distinguishing the unhelpful arguments, based on discredited intellectual assumptions, from those that are relevant for modern debates, even if expressed in an unfamiliar manner or from an unusual perspective. The conceptual looseness of traditional approaches to State responsibility may be paradoxically rewarding for international investment law, since secondary rules of general nature have been elaborated against the backdrop of precisely these primary obligations. To get a sense of systemic issues at play between circumstances precluding wrongfulness and modern investment law, it is useful to first briefly summarise their interaction in the historical perspective.

With all due caution, the general direction of development appears to be away from a broad compendium of various rules on rejection of responsibility, and in the direction of a narrower rubric of circumstances precluding wrongfulness, with systemically more important rules increasingly expressed elsewhere. One approach, taken in the 1927 Draft of the Institute of International Law and the 1929 and 1961 Harvard Draft Conventions, does not deal with circumstances precluding wrongfulness in the modern sense at all, employing loose language of lack of responsibility to cover a variety of secondary and primary rules. ${ }^{10} \mathrm{~A}$ conceptually sharper approach identifies a separate category of circumstances. The Preparatory Committee to the 1930 Hague Conference for the Codification of International Law included self-defence, reprisals, the so-called Calvo Clause, and exhaustion of local remedies in this section, ${ }^{11}$ and the ILC First Special Rapporteur on State Responsibility Garcia-Amador listed necessity, force majeure, and fault of the alien. ${ }^{12}$ The modern list of six circumstances in Part One, Chapter V of the 2001

\footnotetext{
9 J Crawford, State Responsibility: The General Part (CUP 2013) Ch 1; S Wittich, 'State Responsibility' in M Bungenberg and others (eds), International Investment Law: A Handbook (CH Beck/Hart/Nomos 2015) 25-37.

10 'Draft on "International Responsibility of States for Injuries on Their Territory to the Person or Property of Foreigners" Prepared by the Institute of International Law' in 1956 Yearbook of the International Law Commission, Vol. II, UN Doc A/CN.4/96 227 arts III, VII, XII; 'Draft Convention on "Responsibility of States for Damage Done in Their Territory to the Person or Property of Foreigners" Prepared by Harvard Law School' ibid 229 arts 6, 8(2), 13(a), 16(a); 'Draft Convention on the International Responsibility of States for Injuries to Aliens, Prepared by the Harvard Law School, 1961' in 1969 Yearbook of the International Law Commission, Vol. II, UN Doc A/CN.4/217 and Add.1 142.

11 'Bases of Discussion Drawn up in 1929 by the Preparatory Committee of the Conference for the Codification of International Law (The Hague, 1930) (Arranged in Order that the Committee Considered would be the Most Convenient for Discussion at the Conference' in 1956 Ybk ILC (n 10) 223, 224-5.

12 'Third Report on International Responsibility by Mr FV García-Amador, Special Rapporteur' in 1958 Yearbook of the International Law Commission, Vol. II, UN Doc A/CN.4/111 47, 50-5.
} 
ILC Articles - consent, self-defence, countermeasures, force majeure, distress, and necessity -survived essentially intact from the initial work of the Second Special Rapporteur Roberto Ago in $1979-80 .^{13}$

What materials should a contemporary interpreter of investment law, tasked with applying circumstances precluding wrongfulness, have at her fingertips? The starting point is that the law of State responsibility is set out in general customary law, unless special rules of State responsibility have been created, ${ }^{14}$ most likely by treaty law. ${ }^{15}$ Custom, as per the traditional rules on sources, is determined by reference to State practice and opinio juris. The subsidiary means for the determination of rules of law of particular relevance are judicial and arbitral decisions, as well as the work of the ILC. In practice, arbitral tribunals treat the language of the 2001 ILC Articles as accurately expressing customary international law. That calls for three pedantic caveats. First, the 2001 ILC Articles are drafted with the inter-State perspective in mind. Rules expressed therein could therefore be directly applicable, or possibly applicable, or entirely inapplicable to the investor-State framework, as the case for a particular rule in relation to a particular dispute may be. ${ }^{16}$

Secondly, there is something to be said against the excessive enthusiasm of adopting the ILC formulae wholesale. The incremental approach of the International Court of Justice ('ICJ') to necessity provides an appropriate model for the limited judicial function of investment arbitration: the Court has so far accepted five conditions in the 1996 ILC Articles on the issue as reflecting customary law, ${ }^{17}$ only one of them in the language expressed in the 2001 ILC Articles. ${ }^{18}$ Thirdly, the 2001 ILC Articles are not a treaty, and should not be interpreted as such. Part One,

\footnotetext{
${ }^{13}$ Crawford State Responsibility (n 9) 276-8. The fact that particular rules have not made it to the list does not mean that they, the assumptions underlying them, or their structure, are irrelevant for contemporary practice. Some rules originally described as relating to denial of responsibility are now expressed as secondary rules on attribution of conduct and admissibility of claims invoking State responsibility, 2001 ILC Articles (n 1) arts 4-5, 8, 44. Other rules are now addressed as primary obligations on full protection and security, e.g. Trans-Pacific Partnership (concluded 5 October 2015; not in force) <https://ustr.gov/sites/default/files/TPP-Final-Text-Investment.pdf> art 9.6. An interesting example of normative migration is provided by wrongdoings by the alien, discussed as 'fault on the part of the alien' by Garcia-Amador, (n 12) 53-4, and 'clean hands' by Crawford, Crawford State Responsibility (n 9) 278. The rule did not make the final cut, and remains of uncertain authority as a general principle of international law, Yukos Universal Limited (Isle of Man) v Russia, PCA Case no AA 227, Final Award, 18 July 2014 [1357]-[1363]. At the same time, the policy of disapproval of unlawful or improper behaviour by investors has influenced developments regarding jurisdiction of Tribunals, admissibility of claims, compliance with primary obligations, and calculation of damages by reference to contribution to injury.

142001 ILC Articles (n 1) art 55.

15 Al Tamimi (n 2) [321]-[324]. An argument that Argentina could not rely upon necessity because the UK was a persistent objector to this rule was noted but not decided upon in BG Group Plc v Argentina, UNCITRAL Case, Final Award, 24 December 2007 [410] fn 328.

${ }^{16}$ Crawford State Responsibility (n 9) 74-5, 460, 587-92; M Paparinskis, 'Investment Treaty Arbitration and the (New) Law of State Responsibility' (2013) 24 EJIL 617.

${ }_{17}$ Gabčikovo-Nagymaros Project (Hungary/Slovakia) [1997] ICJ Rep 7 [52].

${ }^{18}$ Legal Consequences of the Construction of a Wall in Occupied Palestinian Territories (Advisory Opinion) [2004] ICJ Rep 136 [140].
} 
Chapter V of the 2001 ILC Articles, on some issues formulated as inferences from systemic assumptions, general principles, and primary rules, rather than State practice on secondary rules in the technical sense, could in particular benefit from a consideration of a broad range of materials. ${ }^{19}$ In addition to text and commentaries of the 2001 ILC Articles, these materials would include observations by States to the ILC and the Sixth Committee of the General Assembly, text of the 1996 ILC Articles adopted in the first reading and its commentaries (often addressing issues summarised in the final text in a more expansive manner), relevant reports of the Fifth and Second Special Rapporteurs (respectively James Crawford and Roberto Ago), discussions in the ILC and its Drafting Committee, ${ }^{20}$ and other ILC documents of relevance (e.g. on responsibility of international organisations).

\section{Consent}

Consent is plainly a relevant legal issue for public international law. ${ }^{21}$ Reasonable people may disagree whether consent properly relates to circumstances precluding wrongfulness or particular primary rules, ${ }^{22}$ and why that is relevant in theoretical and practical terms. Be that as it may, consent provides an interesting perspective for discussion of international investment law, which will be pursued in three steps: first considering consent by the home State, then disposing of a few misleading instances, and finally addressing consent by the investor.

The first question is whether the home State of the investor can validly consent to what would otherwise be conduct not in compliance with primary obligations of investment protection by the host State. It is useful to first be clear on what this question is not about. It is not about the in-built qualifications in primary obligations of investment protection regarding conflicts rules, carve-outs, non-conforming measures, denial of benefits, and exceptions. ${ }^{23}$ It is not about general (or special) rules on interpretation, amendment, and termination of treaties that may provide further flexibility to States. ${ }^{24}$ It is also different from a State's approval of

\footnotetext{
${ }_{19}$ This is without prejudice to the question about the best approach to interpretation of ILC Articles more generally, cf. D Caron, 'The ILC Articles on State Responsibility: The Paradoxical Relationship between Form and Authority' (2002) 96 AJIL 857, 867-72; G Gaja, 'Interpreting Articles Adopted by the International Law Commission' (2015) BYBIL doi:10.1093/bybil/brv001 (published online 2 September 2015).

${ }^{20}$ All the ILC's materials relating to State responsibility are available at <http://legal.un.org/ilc/guide/9_6.shtml>.

21 Armed Activities on the Territory of the Congo (DRC v Uganda) [2005] ICJ Rep 168 [42]-[54]; 2001 ILC Articles (n 1) art 20.

22 'Second Report on State Responsibility by Mr James Crawford, Special Rapporteur' UN Doc A/CN.4/498 and Add.1-4 61-2.

${ }^{23}$ TPP Ch 9 (n 13) arts 9.3, 9.11, 9.14; TPP Chapter 29 (Exceptions) <https://ustr.gov/sites/default/files/TPPFinal-Text-Exceptions-and-General-Provisions.pdf $>$.

${ }^{24}$ E.g. the exchange of letters between Laos and the PRC in relation to the territorial scope of their BIT, which reflected Laos' position that had been rejected in an earlier investment arbitration award, and appeared to play a
} 
conduct not in compliance with a primary obligation that has already taken place. Such an expression of will would relate to the power of the State to affect the invocation of responsibility by its investor for a (properly) wrongful act that has already taken place. ${ }^{25}$ And it assumes both that primary obligations on investment protection are such that consent in their regard can be provided in principle, and that the home State has enough of a legal interest in the compliance with the primary obligation to provide consent. The issue becomes clearer when put in colloquial terms: could a party to a BIT, in response to the following question by the other party 'Would you awfully mind if I expropriated that pesky investor of yours without compensation I otherwise have to pay under the BIT?' answer 'That sounds like a jolly good idea'?

Once posed in those terms, a question about consent as a circumstance precluding wrongfulness shows itself, in these circumstances, to really be about suspension of a treaty rule between particular parties in relation to a particular situation, to be answered under the general law of treaties. ${ }^{26} \mathrm{~A}$ somewhat comparable instance of practice is provided by the agreement of Canada and the US to suspend Section B of Chapter Eleven of the NAFTA so that 'no claim under [it] may be made against a Party by investors of the United States or Canada in respect of any such matter or measure ${ }^{27}$ under the 2006 Softwood Lumber Agreement. While related to procedural rather than substantive rules, this treaty is an example of suspension - or reciprocal consent - regarding conduct that could otherwise be unlawful under obligations relating to investment protection. ${ }^{28}$ For law of treaties, effectiveness of such an agreement would be determined by compliance with rules on suspension of particular provisions between particular parties $^{29}$ (effectively turning on whether the particular obligations are bilateralisable or genuinely multilateral). For investment treaty law, the additional question would be whether the presence

substantial role in the domestic review proceedings of that award, Government of the Lao People's Democratic Republic v Sanum Investments Ltd (Judgment) [2015] SGHC 15 [38]-[56], [67]-[78].

${ }^{25}$ E.g. TPP Ch 29 (n 23) art 29.4(8).

26 The distinction drawn by the ILC between the general right of termination and suspension and the narrower consent only for the particular occasion or purpose consented to, Crawford State Responsibility (n 9) 281-3, understates the flexibility of general rules on suspension. Parties may agree to suspend treaties, either in general or among particular parties only, 1969 Vienna Convention on Law of Treaties <https://treaties.un.org/doc/Publication/UNTS/Volume\%201155/volume-1155-I-18232-English.pdf> arts 57, 58 , in relation to particular rules, art 44(3), and, by implication, in relation to application of particular rules to particular circumstances, as the treaty noted in the next footnote does. Still, suspension of treaties may not provide solutions for all cases of consent, e.g. when the source of the obligation is custom or when the primary rule in question permits consent by an official who does not generally have the authority to bind the State internationally. 272006 Softwood Lumber Agreement between Canada and the US (concluded 12 September 2006; not in force 12 October 2015) < http:/ / www.treaty-accord.gc.ca/text-texte.aspx?id=105072\&lang=eng > art XI(2).

28 Incompliance with obligations relating to international dispute settlement can give rise to international responsibility, Interpretation of Peace Treaties (Second Phase) (Advisory Opinion) [1950] ICJ Rep 221, 228-9; see also Mexico's argument in Archer Daniels Midlands Company and Tate \& Lyle Ingredients Americas, Inc. v Mexico, ICSID Case no $\operatorname{ARB}(\mathrm{AF}) / 04 / 05$, Award, 21 November 2007 [110].

${ }^{29} \operatorname{VCLT}(\mathrm{n} 26)$ arts 44(3), 58(1)(b). 
of an investor, particularly if viewed as possessing direct rights analogous to human rights or rights of third parties, affects the validity or opposability of consent. ${ }^{30}$

It may be convenient at this point to dispose of a number of scenarios that only appear to be related to consent. First, since consent is provided before the act takes place, any form of acceptance of lawfulness of an act after it has taken place would fall under the rubric of loss of the right to invoke responsibility, whether by waiver or acquiescence. ${ }^{31}$ Settlement of a claim between an investor and a State is one example of conduct that would affect the right to invoke responsibility, rather than preclude wrongfulness, even if it is with prejudice. The distinction between acceptance of a wrongful act before its commission and after that can have practical consequences for international investment law. When a wrongful act has (allegedly) occurred, invocation of State responsibility accruing directly to the investor will take place through investor-State arbitration and will not be affected by a waiver by the State of its right to invoke responsibility ${ }^{32}$ (unless such effect is prescribed in the relevant secondary rules). ${ }^{33}$ Secondly, the case of suspension of diplomatic protection by consent of the investor, provided for in Article 27(1) of the ICSID Convention, is even further removed from consent discussed in this section. 'Consent' in the ICSID Convention relates to arbitration, rather than preclusion of wrongfulness; it affects implementation of responsibility rather than wrongfulness; and it does not dispose of it conclusively but only suspends it. Thirdly, if forum selection clauses are read as posing admissibility objections to claims under umbrella clauses, ${ }^{34}$ they again go to conditions of implementation of responsibility rather than wrongfulness in the first place. Fourthly, primary obligations may themselves discipline the manner in which States may obtain consent from

\footnotetext{
30 The nature of investors' rights is further discussed in relation to countermeasures in Section IV.

31 Armed Activities on the Territory of the Congo (n 21) [293]; 2001 ILC Articles (n 1) art 45.

32 The distinction is mirrored in the softwood lumber settlement, where NAFTA was suspended prospectively between the US and Canada, n 27, and the outstanding investor-State claims were settled, Agreement Between the Government of Canada and the Government of the United States of America Amending the Softwood Lumber Agreement Between the Government of Canada and the Government of the United States of America Done at Ottawa on 12 September 2006 (concluded 12 October 2006) <http://treaty-accord.gc.ca/texttexte.aspx?id=105075\&lang=eng $>$ Annex 2A.1 (the obvious caveat is that because treaty is drafted in a particular way does not mean that it had to be drafted in that way). Consequently, if, say, Greece and Cyprus were to take the view that the mutually outstanding investor-State claims by respectively Cypriot and Greek investors were best disposed of in an inter-State settlement, their options would be limited. States could not provide retrospective consent to conduct challenged, and waivers could not be opposed to responsibility directly accruing to, and implemented by non-State actors (I leave aside the possibility of an agreement by investors themselves to settle, and avenues noted in the text at nn 23-4). I am grateful to Anastasios Gourgourinis for suggesting this hypothetical.

33 E.g., the right of access of neutral individuals to the International Prize Court was subject 'to the reservation that the Power to which he belongs may forbid him to bring the case before the Court', 1907 Convention (XII) Relative to the Creation of an International Prize <https://www.icrc.org/applic/ihl/ihl.nsf/Treaty.xsp?action= openDocument\&documentId=FEFF373CB0480A04 C12563CD002D685E $>$ art 4(2). The 1967 OECD Draft Convention for the Protection of Foreign Property provided for suspension of the investor's claim if the home State brought its claim, <http://www.oecd.org/investment/internationalinvestmentagreements/39286571.pdf> art 7(d).

${ }^{34}$ BIV AC v Paraguay, ICSID Case no ARB/07/9, Decision on Objections to Jurisdiction, 29 May 2009 [143]-[161].
} 
investors in their mutual dealings, e.g. by basing international responsibility on duress. ${ }^{35}$ Fifthly (and somewhat conversely), some primary obligations may take into account consent in evaluating whether the breach has taken place. ${ }^{36}$ For example, in the human rights context, unequivocal and informed waiver may be possible regarding right to fair trial but not nondiscrimination $^{37}$ (whether this distinction also provides a sensible solution for primary obligations of investment law, in light of their object and purpose, is a question best answered elsewhere). ${ }^{38}$

Can an investor properly consent to conduct otherwise not in compliance with a primary obligation regarding investment? If the State's question focuses on procedure -- 'Would you awfully mind consenting not to sue me before investment treaty tribunals? ${ }^{39}$ - it may relate to consent as a circumstance precluding wrongfulness, but also to implementation of responsibility, discussed above. But it could be clearly directed at the permissible conduct of the State: 'If I grant you a lucrative licence, would you mind if I were to change the regulatory and tax regime in whatever manner and whenever I feel like it, and take away your earnings once in a while?? If this question is read as going to consent, rather than scope of protected investment, could an investor answer, with legal effect: 'For getting a licence such as this, it sounds perfectly acceptable'? The question of principle may be answered in two ways. For the SGS v Philippines Tribunal, '[i]t is, to say the least, doubtful that a private party can by contract waive rights or dispense with the performance of obligations imposed on the States parties to those treaties under international law'; ${ }^{40}$ for the Hocbtief $v$ Argentina Tribunal, 'there is no legal reason why effect should not be given to an agreement between an investor and a host State either to limit the rights of the investor or to oblige the investor not to pursue any remedies, including its BIT remedies, in certain circumstances' ${ }^{41}$ The choice between these answers is hard, and rightly so: it directly touches upon assumptions about object and purpose as well as mechanics of investment

35 Desert Line Projects LLC v Yemen, ICSID Case no ARB/05/17, Award, 6 February 2008 [148]-[194].

${ }^{36}$ Crawford State Responsibility (n 9) 287.

37 Cf. App. No. 25703/11, Dvorski v Croatia, [GC] ECHR Judgment of 20 October 2015 [100]-[101]; App. No 30078/06, Konstantin Markin v Russia, [GC] ECHR Rep 2012 [150].

38 The challenge of distinguishing consent in these two guises supports scepticism about the value of the category of circumstances precluding wrongfulness. Does it really make sense to treat Russia's acceptance of repayment of the principal amount without interest in Russian Indemnities as a 'circumstance precluding wrongfulness', Crawford State Responsibility (n 9) 285, and arguments about identical conduct by an investor as a part of the definition of the primary obligations? There may be good reasons, both normative and aesthetic, for addressing an issue either as part of a particular rule or by cross-cutting rules on excuse, defence, or justification. Important practical consequences may follow in terms of burden of proof or compensation. But employing the rubric of circumstances precluding wrongfulness does not obviously assist with resolving these questions, even when they are dealt with in an explicit manner, see regarding compensation in Section VII.

39 S Perry, 'Colombia drops treaty claim waiver provision' Global Arbitration Review (13 December 2013).

40 SGS Société Générale de Surveillance S.A. v Philippines, ICSID Case no ARB/02/6, Decision on Objections to Jurisdiction, 29 January 2004 [154].

${ }^{41}$ Hochtief v Argentina, ICSID Case no ARB/07/31, Decision on Liability, 29 December 2014 [191], generally [190][194]. The language used by the Tribunal is suggestive of consent: 'Such an agreement does not purport to alter the terms of the Treaty. ... It may also be regarded as an agreement by the investor not to rely upon certain treaty provisions and extant rights in the specified circumstances', ibid [191]. 
treaty law, and the structure of international law more broadly. ${ }^{42}$ For example, consent may be more fitting in a regime set up to nudge investment-related decisions in a particular direction than in a regime addressing rule of law considerations. ${ }^{43}$ The final point is more pedestrian: has consent been given in a particular instance? The answer is a matter of interpretation. ${ }^{44}$ But there is something to be said, in the modern world of overlapping legal orders through which nonState actors slide in an increasingly effortless manner, for not imposing overly ritualistic conditions for engagement with international law.

\section{Self-defence}

Whether or not characterising self-defence as a secondary rule ${ }^{45}$ performs a useful function - a point to be considered below - it is (also) a primary rule. The right to self-defence is part of the regime on jus ad bellum set out in the UN Charter and customary international law. Use of force falling under self-defence is plainly lawful, rather than unlawful with precluded wrongfulness. ${ }^{46}$ But self-defence does provide a useful perspective for a brief discussion of how international investment law deals with the international law of war, both in its jus ad bellum and jus in bello incarnations (with some inevitable sloppiness regarding the finer distinctions in those bodies of law). Unsurprisingly, war often affects economic interests of individuals in a manner that gives rise to international disputes, from the First ${ }^{47}$ and Second World Wars ${ }^{48}$ to the more recent invasion of Kuwait by $\operatorname{Iraq}^{49}$ and the conflict between Eritrea and Ethiopia. ${ }^{50}$ These questions are likely to be of importance for dispute settlement in international investment law.

It may be convenient to consider in turn four issues. First, what is the effect of war as a matter of law of treaties? The ICJ cases that address Friendship, Commerce, and Navigation ('FCN') Treaties against the backdrop of unlawful use of force suggest, by necessary implication, that such treaties are not automatically suspended or terminated. ${ }^{51}$ The ILC work on treaties and armed conflict has proceeded from the starting point of lack of automatic suspension, adding

\footnotetext{
42 Lowe (n 8) 409.

${ }^{43}$ Cf. Z Douglas, The International Law of Investment Claims (CUP 2009) 135-6; BIICL, Risk and Return: Foreign Direct Investment and the Rule of Law (3 June 2015) < http://www.biicl.org/documents/625_d4_fdi_main_report.pdf>.

${ }^{44} \mathrm{Cf}$. what appear to be more and less strict approaches, albeit in relation to differently drafted contractual clauses, Aguas del Tunari v Bolivia, ICSID Case no ARB/02/3, Decision on Objections to Jurisdiction, 21 October 2005 [118]-[122]; Hochtief (n 41) [189], [192].

452001 ILC Articles (n 1) art 21.

46 Legal Consequences of the Construction of a Wall in Occupied Palestinian Territories (n 18) [139].

47 Recueil des décisions des Tribunaux arbitraux mixtes: institués par les traités de paix (Volumes 1-10, Recueil Sirey 1922-30).

48 13-14 RIAA.

${ }^{49}$ United Nations Compensation Commission, <http://www.uncc.ch/>.

${ }^{50}$ Eritrea-Ethiopia Claims Commission, <http://www.pcacases.com/web/view/71>.

51 Military and Paramilitary Activities in and against Nicaragua (Nicaragua v US) (Merits) [1986] ICJ Rep 14 [219], [270][282]; Oil Platforms (Iran v US) [2003] ICJ Rep 161 [41].
} 
that the two elements to be taken into account to determine whether a treaty is susceptible of withdrawal, termination, or suspension are the nature of armed conflict and the nature of treaty. ${ }^{52}$ Investment treaties as 'agreements concerning private rights', similarly to FCN Treaties, are viewed by the ILC as having the subject-matter that carries the implication of continued operation. ${ }^{53}$ Secondly, do the primary obligations of investment protection address armed conflict? Much, of course, depends on the facts, but claims relating to conflict and troops could be conceivably framed in terms of full protection and security, ${ }^{54}$ fair and equitable treatment, ${ }^{55}$ and what modern treaties call 'treatment in case of armed conflict or civil strife' ${ }^{56}$ (having taken not much longer than half a century to catch up with the diminished role of 'war' as a term of art and a legal institution ${ }^{57}$ ). Thirdly, is interpretation and application of investment law in this context likely to raise questions about other primary regimes of international law? So far, arbitral decisions have addressed armed conflict in a rather insular, if not clinically isolated, manner. One hopes that future developments, perhaps to some extent echoing sophisticated analysis of intersections between regimes in comparable contexts, ${ }^{58}$ will take greater advantage of the robust bodies of relevant rules of humanitarian and human rights law. ${ }^{59}$ A caution of not venturing too close to or beyond the jurisdictional four corners entrusted to the tribunal ${ }^{60}$ (if that is what explains arbitral reticence) is commendable. But positive law of treaties already provides interpreters with sufficiently sophisticated tools for engaging with other relevant regimes. ${ }^{61}$

Fourthly, is there something in addition to the points already made that self-defence can contribute as a circumstance precluding wrongfulness? There are elements of practice, including

$52 \quad 2011$ ILC Draft Articles on the Effects of Armed Conflicts on Treaties $<$ http://legal.un.org/docs/?path=../ilc/texts/instruments/english/draft_articles/1_10_2011.pdf\&lang=EF> arts 3,6 .

53 Ibid art 7, Annex (e); 2011 ILC Draft Articles on the Effect of Armed Conflicts on Treaties with Commentaries $<$ http://legal.un.org/docs/?path=../ilc/texts/instruments/english/commentaries/1_10_2011.pdf\&lang=EF>

Annex Commentary [26]-[38], [48], [69]. Although see an authority that appears to be at least partly inconsistent, suggesting that bilateral treaties of economic nature, including a trade treaty in the particular case, are at the very least suspended by war, Economic Loss throughout Ethiopia-Ethiopia's Claim 7 (Partial Award) (2005) 26 RIAA 445 [15], [18]; S Murphy and others (eds), Litigating War (OUP 2013) 390-93. A qualified argument for permissibility of suspension is made in J Ostřanský, 'The Termination and Suspension of Bilateral Investment Treaties Due to an Armed Conflict' (2015) 6 J Int'l Dispute Settlement 136.

${ }^{54}$ AAPL v Sri Lanka, ICSID Case no ARB/87/3, Final Award, 21 June 1990 [72]-[86].

55 Military and Paramilitary Activities in and against Nicaragua (n 51) [277]; Toto Costruzioni Generali SPA v Lebanon, ICSID Case no ARB/07/12, Award, 7 June 2012 [201]-[206].

${ }^{56}$ TPP Ch 9 (n 13) arts 9.6bis.

57 Although certain legal regimes traditionally associated with the concept of war may have been surprisingly resilient, see J Upcher, Neutrality in Contemporary International Law (OUP 2016) (forthcoming).

${ }^{58}$ L Hill-Cawthorne, 'Humanitarian Law, Human Rights Law and the Bifurcation of Armed Conflict' (2015) 64 ICLQ 293.

59 I Ryk-Lakhman, 'Back to Basics: Interpretation of Bilateral Investment Treaties in Times of Armed Conflicts' (The $3^{\text {rd }}$ Annual TAU Workshop for Junior Scholars in Law, 26-7 October 2015, on file with the author).

${ }^{60}$ Hesham Talaat Al-Warraq v Indonesia, UNCITRAL Case, Final Award, 15 December 2014 [556]-[621].

${ }^{61}$ The Rompetrol Group BV v Romania, ICSID Case no ARB/06/3, Award, 6 May 2013 [169]-[172]; M Paparinskis, The International Minimum Standard and Fair and Equitable Treatment (OUP 2013) Chs 7-9. 
in relation to commercial matters, which suggest that self-defence precludes wrongfulness for other breaches that are collateral to the use of force in self-defence. ${ }^{62}$ As often is the case when the existence of a customary rule is debated, a more sceptical reader might distinguish these instances as relating to the operation of, or exceptions within other primary rules. The sceptic would find support in Oil Platforms, where the issue of self-defence in terms of the 2001 ILC Articles was put squarely before the ICJ. ${ }^{63}$ The relationship between the law of self-defence and the FCN Treaty was a key interpretative controversy in the case, ${ }^{64}$ but neither the Court nor the Judges writing individually found the perspective of State responsibility to be sufficiently relevant even to be explicitly rejected. ${ }^{65}$ Finally, whatever the best answer more generally, it may be that the question will simply not be posed in these terms in investment law. The first treaty case about fair and equitable treatment -- Nicaragua's claim that the US had breached its obligation 'not to kill, wound or kidnap Nicaraguan citizens in Nicaragua ${ }^{96}$ - may be taken as an example. If presented before an investor-State Tribunal, the claim would be strained to satisfy the usual jurisdictional requirements of 'an investment' made 'in the territory' of the host State. Even if it did, particular allegations - as many other conceivable breaches of investment law -- would not be collateral to use of force in self-defence. Concerns regarding armed conflict may be better articulated through interpretation of primary obligations and exceptions of investment law, taking into account primary rules from other regimes, or indeed application of other circumstances precluding wrongfulness like countermeasures, distress, or necessity.

\section{Countermeasures}

Can a State preclude wrongfulness for the breach of primary obligations of investment protection by invoking countermeasures in response to an anterior breach of international law? Reasonable people have disagreed about the best answer. Dionisio Anzilloti was certain that

\footnotetext{
${ }^{62}$ F Paddeu, 'Self-Defence as a Circumstance Precluding Wrongfulness: Understanding Article 21 of the Articles on State Responsibility' (2015) BYBIL doi: 10.1093/bybil/brv015 (published online 21 October 2015) 29-41.

63 Oil Platforms (Iran v US), Verbatim Record, 17 February 2003, CR 2003/5 <http://www.icjcij.org/docket/files/90/5129.pdf> 41 [29] (Crawford on behalf of Iran); ibid 19 February 2003, CR 2003/7 <http://www.icj-cij.org/docket/files/90/5137.pdf> 35 [18] (Bothe on behalf of Iran), 51 [3] (Crawford on behalf of Iran).

${ }^{64}$ F Berman, 'Treaty “Interpretation” in a Judicial Context' (2004) 29 Yale J Int'l L 315.

65 Oil Platforms (n 47), with the possible exception of Separate Opinion of Judge ad hoc Rigaux 362, 383-4. The reaction to the judgment in State practice and legal writings, while often critical, has not focused on the choice to treat circumstances precluding wrongfulness as irrelevant, 'U.S. Reaction to ICJ Judgment in Iranian Oil Platforms Case' (2004) 98 AJIL 597; W Taft IV, 'Self-Defense and the Oil Platforms Decision' (2004) 29 Yale J Int'l L 295; Berman ibid; E Cannizzaro and B Bonafé, 'Fragmenting International Law through Compromissory Clauses? Some Remarks on the Decision of the ICJ in the Oil Platforms Case' (2005) 16 EJIL 481.

66 The claim was rejected because the conduct of contras was not attributable to the US, Military and Paramilitary Activities in and against Nicaragua (n 51) [277].
} 
countermeasures provided a special exception to the general principle of protection of private property of foreigners. ${ }^{67}$ Conversely, García-Amador suggested that '[n]owadays it would be difficult to admit ... that reprisals can constitute grounds for exoneration from responsibility ${ }^{68}$ Under contemporary international law, countermeasures are plainly accepted as a circumstance precluding wrongfulness. ${ }^{69}$ But an international investment lawyer could find it slightly odd if a respondent State, in response to an investment claim, were to say 'Awfully sorry for mistreating your investment in breach of my investment obligations but you must appreciate that it is not personal: just a gentle nudge to your home State to resume compliance with its own obligations, precisely what international law on implementation of responsibility is all about'. It may be convenient to address in turn two ways in which the normative intuition of oddness may be articulated in legal terms: first, can countermeasures be invoked in principle to preclude wrongfulness for the breach of investment obligations? Secondly, can countermeasures be realistically invoked in relation to investment obligations, as they are drafted?

The starting point for thinking about the first question is that the right to take countermeasures is a dispositive rule, and may be superseded by lex specialis. ${ }^{70}$ Has this taken place in international investment law? ${ }^{71}$ The argument in favour of an affirmative answer could be presented in several ways. The first would rely on subject-matter: international investment law addresses important and sensitive issues, which would be greatly harmed by arbitrary interferences by States, by reference to inter-State disputes. On its own, such reliance on content of primary obligations would be insufficient. ${ }^{72}$ Secondly, if States owe obligations directly to investors, could they really be permitted to breach them in response to conduct by other States? ? $^{73}$ That is a valid point, but it conflates exclusion of secondary rules in principle and the practical

${ }^{67}$ Cited in Oscar Chinn Case (Great Britain v Belgium) PCIJ Rep Series C 7553 (Case of the Government of Great Britain).

68 García-Amador (n 12) 55 [25].

69 Application of the Interim Accord of 13 September 1995 (FYRM v Greece) [2011] ICJ Rep 644 [164]; 2001 ILC Articles (n 1) arts $22,49-54$.

702001 ILC Articles (n 1) art 55.

${ }^{71}$ M Paparinskis, 'Investment Arbitration and the Law of Countermeasures' (2008) 79 BYBIL 264, 345-51.

${ }^{72}$ In the leading modern case, countermeasures were applicable even though 'the network of air services is in fact an extremely sensitive system, disturbances of which can have wide and unforeseeable consequences', Air Service Agreement of 27 March 1946 between the United States of America and France (1978) 18 RIAA 417, 445 [92]. A narrower argument would focus on primary obligations that are explicitly or by necessary implication directed at countermeasures as such. For example, Libya engaged in expropriation as an ostensible countermeasure against the UK, BP v Libya, Award, 10 October 1973 (1979) 53 ILR 297, 329, and the UK BIT practice expresses the first condition of lawfulness of expropriation as 'public purpose related to the internal needs of that Party', e.g. EgyptUK BIT < http://investmentpolicyhub.unctad.org/Download/TreatyFile/1122> art 5(1), which a countermeasure would find hard to satisfy. As a matter of effectiveness of interpretation, it would be odd if a breach of a primary obligation that attaches responsibility to a countermeasure could be excused by relying on a countermeasure.

73 Z Douglas, 'Specific Regimes of Responsibility: Investment Treaty Arbitration' in J Crawford, A Pellet and S Olleson (eds), The Law of International Responsibility (OUP 2010) 820-1. 
limitations of their application to primary rules drafted in a particular manner. ${ }^{74}$ Another argument would be to look more broadly at the system of international investment law, and rely on its efficiency and coherence, particularly as reflected in the recent mega-regional treaties and proposals, to suggest that the backdrop of general rules on implementation of responsibility must fade as against this special structure. ${ }^{75}$ A yet different, or at least differently focused, argument would rely upon the framing of modern investment dispute settlement law around the investor-State axis as excluding the application of remedies and procedures from traditional inter-State law. ${ }^{76}$ The lex specialis argument was considered in three NAFTA claims against Mexico regarding soft drinks. One Tribunal rejected it explicitly, one by necessary implication, one did not address it at all, ${ }^{77}$ and one arbitrator wrote a short separate opinion, finding countermeasures inapplicable due to a mixture of purposive and procedural arguments. ${ }^{78}$ There is something to be said for a generalist preference regarding the question of principle, at least partly because the practicalities for successful invocation may often be insurmountable. ${ }^{79}$

One starting point for thinking about the practicalities is the position regarding countermeasures and international human rights law - for the purpose of State responsibility, a regime similar to investment law in that it also permits invocation of responsibility by non-State actors on their own account and without the intermediation of any State. ${ }^{80}$ The 2001 ILC Articles address the issue in Article 50(1)(a), which provides that '[c]ountermeasures shall not affect ... obligations for the protection of fundamental human rights'. The rationale of this proposition is unclear. ${ }^{81}$ Is 'fundamental human rights' a normative statement about a particular category of lex specialis? Or does it suggest a dichotomy between application of countermeasures to 'fundamental' and less important human rights? If so, does one draw the line between rights peremptory/dispositive, customary/treaty, non-derogable/derogable, or in some other way? Or is the point that human rights obligations are structurally erga omnes, and countermeasures vis-à-vis

\footnotetext{
${ }^{74} \mathrm{~K}$ Parlett, 'The Application of the Rules on Countermeasures in Investment Claims' in C Chinkin and F Baetens (eds), Sovereignty, Statehood and State Responsibility: Essays in Honour of James Cranford (CUP 2015) 403-4.

75 B Simma and D Pulkowski, 'Leges speciales and Self-Contained Regimes' in J Crawford, A Pellet and S Olleson (eds), The Law of International Responsibility (OUP 2010).

${ }^{76}$ Article 33(2) of the 2001 ILC Articles (n 1), which provides for a without prejudice rule regarding responsibility accruing to non-State actors, could not be relied upon for making this argument: it applies only to Part Two, and countermeasures inhabit Parts One and Three of the 2001 ILC Articles.

77 Respectively Archer Daniels Midlands (n 28) [120]-[123]; Corn Products International, Inc. v Mexico, ICSID Case no $\operatorname{ARB}(\mathrm{AF}) / 04 / 01$, Decision on Responsibility, 15 January 2008 [165]; Cargill, Inc. $v$ Mexico, ICSID Case no ARB(AF) $/ 05 / 2$, Award, 18 September 2009 [429].

78 Corn Products ibid Separate Opinion of Arbitrator Lowenfeld.

${ }^{79} \mathrm{D}$ McRae and E Van Zimmeren, 'Countermeasures and Investment Arbitration' in M Kinnear and others (eds), Building International Investment Law: The First 50 Years of ICSID (Kluwer Law International 2015) 497-9.

802001 ILC Articles on State responsibility for internationally wrongful acts with Commentaries <http://legal.un.org/ilc/texts/instruments/english/commentaries/9_6_2001.pdf> art 33(2) Commentary 4.

81 S Borelli and S Olleson, 'Obligations Relating to Human Rights and Humanitarian Law' in J Crawford, A Pellet and S Olleson (eds), The Law of International Responsibility (OUP 2010) 1182-6.
} 
a wrongdoing State will not be opposable to other parties to the obligation? Or, finally, should one rather apply the same point about opposability of countermeasures only to the wrongdoer ${ }^{82}$ so as to protect individual beneficiaries of human rights, akin to third parties? Various readings of the rationale of these general rules on countermeasures could have different impact for investment law. ${ }^{83}$ Say, if Article 50(1)(a) follows from the multilateral structure of human rights obligations, it would have little application to the prima facie bilateralisable investment law, ${ }^{84}$ while an analogy between non-State actors and third parties could have greater relevance, and so on.

The three NAFTA Tribunals dealing with soft drinks claims read the law of responsibility, at least by implication, along the lines suggested by the Fifth Special Raporteur in his Third Report:

The position with respect to human rights is at one level the same as the position with respect to the rights of third States. Evidently, human rights obligations are not owed to States as the primary beneficiaries, even though States are entitled to invoke those obligations and to ensure respect for them. Thus it is obvious that human rights obligations (whether or not qualified as "basic" or "fundamental") may not themselves be subject to countermeasures, ... and that conduct inconsistent with human rights obligations may not be justified or excused except to the extent provided for by the applicable regime of human rights itself. ${ }^{85}$

To determine whether ' $\mathrm{t}$ ] he position with respect to [investor] rights is at one level the same as the position with respect to the rights of third States', the right question to ask is whether primary obligations under investment law are owed to investors. Reasonable people may disagree about the general issue. ${ }^{86}$ But the answer to this particular question will be provided by the interpretation of the particular obligation in the particular treaty, to which the discussion regarding 'individual rights' in the LaGrand case could provide some methodological guidance. ${ }^{87}$ Tribunals have answered the interpretative question differently. For (the majority of) one Tribunal, Chapter 11 of NAFTA expresses primary obligations only at the inter-State level, therefore countermeasures can preclude wrongfulness for their breach, ${ }^{88}$ provided that other

\footnotetext{
822001 ILC Articles (n 1) art 49(1).

${ }^{83}$ Paparinskis 'Investment Arbitration and the Law of Countermeasures' (n 71) 317-45.

${ }^{84} \mathrm{D}$ Azaria, Treaties on Transit of Energy via Pipelines and Countermeasures (OUP 2015) 130-6.

85 'Third Report on State Responsibility by Mr James Crawford, Special Rapporteur' UN Doc A/CN.4/507 and Add.1-4 [349].

${ }^{86}$ Cf. Douglas The International Law of Investment Claims (n 43) Ch 1; R Volterra, 'International Law Commission Articles on State Responsibility and Investor-State Arbitration: Do Investors Have Rights?' (2010) 25 ICSID RevForeign Investment L J 218.

87 LaGrand (Germany v US) [2001] ICJ Rep 466 [75]-[77]; Separate Opinion of Vice-President Shi 518; Dissenting Opinion of Judge Oda [23]-[25]. With all due caution in light of the very significant constitutional and procedural differences, a source of inspiration could be provided by decisions of the Court of Justice of the European Union regarding individual rights and direct effect of international treaties, Joined Cases C-404/12 P and C-405/12 P, Council of the EU and EC v Stichting Natuur en Milieu and Pesticide Action Network Europe [2015] [GC] ECLI:EU:C:2015:5 [44]-[53]; P Eeckhout, EU External Relations Law (2nd edn, OUP 2011) 331-55.

88 Archer Daniels Midlands (n 28) [161]-[180].
} 
criteria of countermeasures - particularly adoption in response to an alleged breach and proportionality of the measures -- have been met (they were not). ${ }^{89}$ For two Tribunals, as well as one arbitrator of the first Tribunal writing separately, investors did have rights under NAFTA, and countermeasures regarding their home State could not be opposed to those rights. ${ }^{90}$ Consequently, while Mexico's argument was rejected in all cases, the first but not the second position leaves open the possibility of successful invocation of countermeasures, provided that structural and procedural conditions are complied with. ${ }^{91}$ (The usual caveat is that these decisions turned on interpretation of NAFTA, therefore one should carefully consider the extent to which their reasoning is transposable to other rules regarding investment protection.)

Both responses are problematic in their own way. If countermeasures can be invoked against investors, how does one synchronise the inter-State perspective of countermeasures with the investor-State perspective of investment arbitration? If a Tribunal of limited personal and subject-matter jurisdiction, which plainly does not extend to deciding upon responsibility of the home State, were to consider such allegations, it may be sailing too close to boundaries of its authority, in particular regarding pronouncements on rights of indispensable third parties. ${ }^{92}$ At the same time, there may be troubling systemic implications if a colourable argument of countermeasures sufficed to defeat admissibility of an investment claim. ${ }^{93}$ Conversely, if countermeasures cannot be taken against investors, is there any utility in taking them at all? ${ }^{94}$ The first possible response, to borrow from the block quote above, is that conduct inconsistent with investment obligations may be justified or excused ... to the extent provided for by the applicable regime', and rules on denial of benefits and exceptions may (be drafted to) provide such an excuse. Secondly, the law of countermeasures may be creatively rethought or progressively developed so as to permit qualified reliance on countermeasures. ${ }^{95}$ Thirdly, perhaps there is no utility, and one should welcome that. If unilateral self-help measures, often likely to play to the strength of Powers That Be, ${ }^{96}$ cannot be removed from the international legal order

\footnotetext{
892001 ILC Articles (n 1) arts 49, 51-3. The Archer Daniels Midlands Tribunal concluded that conduct in question had not been enacted in response to the alleged breach by the US, was not intended to induce compliance by the US with its obligations, and was not proportionate, (n 28) [134]-[160].

90 Corn Products (n 77) [161]-[179]; Cargill (n 77) [420]-[428]; Archer Daniel Midlands (n 28) Concurring Opinion of Arbitrator Rovine, 20 September 2007.

912001 ILC Articles (n 1) arts 49, 51-3.

92 Chevron Corporation and Texaco Petroleum Company v Ecuador, PCA Case no 2009-23, Third Interim Award on Jurisdiction and Admissibility, 27 February 2012 [4.60]-[4.63]; Philippines v China, PCA Case no 2013-19, Award on Jurisdiction and Admissibility, 29 October 2015 [181].

93 ADM Rovine (n 90) fn 56.

94 Parlett (n 74) 404.

${ }^{95} \mathrm{JJ}$ Losari and M Ewing-Chow, 'A Clash of Treaties: The Lawfulness of Countermeasures in International Trade Law and International Investment Law' (2015) 16 J World Trade Investment 274; A Roberts, 'Triangular Treaties: The Extent and Limits of Investment Treaty Rights' (2015) 56 Harvard Int'l L J 353, 399-402.

${ }^{96}$ M Koskenniemi, 'Solidarity Measures: State Responsibility as a New International Order?' (2002) 72 BYBIL 337.
} 
immediately and explicitly, perhaps tying them down to effective irrelevance through the accretion of small drafting print of particular rules, Gulliver-like, is a development to be welcomed. ${ }^{97}$ Overall, a critical reflection on the current majority position -- that countermeasures cannot be opposed to investors - is most likely to occur at the intersection of investment law with the two areas where countermeasures regarding economic interests are taken in a systematic manner in contemporary practice: the WTO, ${ }^{98}$ and third-party countermeasures. ${ }^{99}$

\section{Necessity}

Necessity is a prime example of development of international law by resignation. It is hard to see how the formulae of Article 25 of the 2001 ILC Articles, routinely applied in investment arbitration (and not challenged in post-2001 international dispute settlement more generally), could be reflective of State practice and opinio juris. But once the issue is accepted, in a loose sense, as properly falling within the scope of regulation of international law in some manner, it is equally hard to see how State practice and opinio juris could be mustered to identify a more persuasive rule. ${ }^{100}$ The story of interaction between modern investment law and necessity can be told, almost exclusively, through the rich and diverse decisions in ICSID cases on claims regarding the Argentinean crisis of the early 2000s, mostly those brought by the US investors. The sophistication and nuance of legal writings on these matters is such that it is permissible to refer the more demanding reader to them. ${ }^{101}$ Instead, it may useful to consider two reasons why,

\footnotetext{
${ }^{97}$ Not everybody will share this normative intuition, A Tzanakopoulos, Disobeying the Security Council (OUP 2011) Ch 7; M Dawidowicz, 'Third-party Countermeasures: Observations on a Controversial Concept' in C Chinkin and F Baetens (eds), Sovereignty, Statehood and State Responsibility: Essays in Honour of James Crawford (CUP 2015).

${ }^{98}$ C Brown and J Pauwelyn, The Law, Economics and Politics of Retaliation in WTO Dispute Settlement (CUP 2010).

${ }^{99}$ EJ Criddle, 'Humanitarian Financial Intervention' (2013) 24 EJIL 583, 595-601.

100 The EDF annulment committee recently put the point in these terms: 'It is true that Argentina questioned whether all of the detail of Article 25 reflected customary international law and disputed what it described as the Claimants' propensity to "refer to each of the paragraphs of Article 25 as though it were the final text of a treaty in full force and effect". At no point, however, did Argentina indicate what aspects of Article 25 it considered did not reflect customary international law. Nor, more importantly, did it at any stage advance a positive case in favour of a standard of necessity materially different from that set out in Article 25', EDF International SA, Saur International $S A$ and Leon Participaciones Argentinas SAv Argentina, ICSID Case no ARB/03/23, Decision of the ad hoc Annulment Committee, 5 February 2016 [319].

101 A Bjorklund, 'Economic Security Defenses in International Investment Law' (2008-09) Yearbook Int'l Investment L Policy 479; C Binder, 'Changed Circumstances in Investment Law: Interfaces between the Law of Treaties and the Law of State Responsibility with a Special Focus on the Argentine Crisis' in C Binder and others (eds), International Investment Law for the 21 $1^{\text {st }}$ Century: Essays in Honour of Christoph Schreuer (OUP 2009); J Kurtz, 'Adjudging the Exceptional at International Investment Law: Security, Public Order and Financial Crisis' (2010) 59 ICLQ 325; J Alvarez, 'The Public International Law Regime Governing International Investment' (2011) 344 Hague Recueil 197, Chapter IV; D Dieserto, Necessity and National Emergency Clauses (Brill 2012); R Sloane, 'On the Use and Abuse of Necessity in the Law of State Responsibility' (2012) 106 AJIL 447; P Tomka, 'Defenses Based on Necessity under Customary International Law and on Emergency Clauses in Bilateral Investment Treaties' in M Kinner and others (eds), Building International Investment Law: The First 50 Years of ICSID (Kluwer Law International 2015).
} 
at least for the inquiry into necessity, there's less to Argentinean cases than meets the eye. The first reason is systemic. The multiplicity of procedural strands should not disguise the underlying core similarities. The conduct giving rise to State responsibility was either the same or adopted against the backdrop of the same crisis in all disputes. The manner in which legal issues were dealt with in the arbitral setting was to a considerable extent influenced by procedural choices by the (same) respondent State. It is a trite point that international law is a decentralised legal order, developing through slow and gradual identification, accommodation, and finessing of varied interests of varied actors in varied settings. Argentinean decisions, impressive as they are in quantitative terms, relate to arguments by one State regarding one crisis; one should resist the temptation to equate (lack of) consensus in this setting with the position of international law more generally.

The second question is more pedestrian: what is it that Argentinean cases tell us about necessity? Taking stock of the whole body of decisions rendered, one possible response is 'not much'. The first ICSID awards in mid-2000s did revolve around the substance of necessity, due to the (somewhat peculiar) manner in which Argentina presented its argument on the crisis. ${ }^{102}$ But gradually the focus shifted elsewhere, as international lawyers preferred to talk about any topic - be that primary and secondary rules, ${ }^{103}$ law and economics, ${ }^{104}$ primary rules expressed as obligations, ${ }^{105}$ or primary rules expressed as exceptions ${ }^{106}$ - provided that they could evade addressing necessity as a secondary rule head on. ${ }^{107}$ The combined effect of these methodological and normative qualifications, if accepted, is to cast significant doubts on key assumptions underpinning everything said about necessity in the early decisions. If read with the most critical eye, Argentinean decisions confirm that necessity can be invoked regarding economic and financial crises - a proposition that would not have surprised international lawyers a century ago. ${ }^{108}$ Even more charitable commentators might take the view that these decisions do little to contribute to consensus; the muddying of waters by arbitral or doctrinal authority for nearly every imaginable construction of necessity makes discussion of application of necessity to

\footnotetext{
102 M Waibel, 'Two Worlds of Necessity in ICSID Arbitration: CMS and LG\&E' (2007) 20 Leiden J Int'l L 637. 103 CMS Gas Transmission Company v Argentina, ICSID Case no ARB/01/8, Decision on the Application for Annulment, 25 September 2007 [119]-[136]; Sempra Energy International v Argentina, ICSID Case no ARB/02/16, Decision on the Application for Annulment of the Award, 29 June 2010 [159]-[223].

104 Enron Creditors Recovery Corp. Ponderossa Assets LP v Argentina, ICSID Case no ARB/01/3, Decision on the Application for Annulment, 30 July 2010 [355]-[395].

105 Hochtief (n 41) fn 220, [301]; EDF annulment (n 99) [306]-[316].

106 Continental Casualty Company v Argentina, ICSID Case no ARB/03/9, Decision on the Applications for Partial Annulment, 16 September 2011 [110]-[143].

107 One recent exception is Total SA $v$ Argentina, ICSID Case no ARB/04/1, Decision on Annulment, 1 February 2016 [233]-[239], [286]-[288].

1082001 ILC Articles with Commentaries (n 80) Article 25 Commentaries 7-8.
} 
investment obligations challenging. ${ }^{109}$ State practice, to the extent that it can be inferred from recent treaty-making efforts, endorses the shift away from articulation of emergency concerns in terms of secondary rules. Treaties do not elaborate general or create special secondary rules explicitly, do not (appear to) use technical terms of art that would carry that significance by implication, and express exceptions at the level of primary obligations. ${ }^{110}$ To conclude, necessity may be invoked regarding 'essential interests' of the kind that motivate States to breach their investment obligations in times of crises. It is less obvious that the experience of the last decade has left much enthusiasm among investment law-makers and adjudicators to evaluate the handling of crises in terms of general circumstances precluding wrongfulness. The increasingly fine-grained obligations and exceptions within primary rules appear to provide a more appropriate legal framework.

\section{Compensation}

Not everything in the world is about money, even in international investment law. But it is not surprising that compensation is important for a regime of international law that is shaped to a considerable extent by ex post adjudication. What, if anything, is the obligation of the State that successfully invokes a circumstance precluding wrongfulness regarding breach of its investment obligations? Article 27(b) of the 2001 ILC Articles provides that ' $t$ t $]$ he invocation of a circumstance precluding wrongfulness in accordance with this chapter is without prejudice to ... [t] he question of compensation for any material loss caused by the act in question'. A good starting point for thinking about the issue is to identify what this proposition is not about. It is not a rule on reparation for a wrongful act of the kind set out in Part Two of the 2001 ILC Articles. It does not relate to cases where primary rules have been complied with and no compensation is due. And it is 'itself a "without prejudice" clause, not a stipulation' of circumstances in which compensation could be due. ${ }^{111}$ It is less clear in what circumstances compensation is, in fact, due. The ILC's record is helpful only in confirming the thinness of consensus and paucity of directly relevant practice. The ILC considered proposals for excluding compensation either for cases of countermeasures and self-defence only, or for consent and force majeure as well; observations by States ranged from having compensation for necessity and distress, and for necessity only, to referring back to primary rules and (apparently) no

\footnotetext{
109 M Mendelson and M Paparinskis, 'Bail-ins and the International Investment Law of Expropriation: in and beyond Cyprus' (2013) J Int'l Banking Financial L 475, 478.

110 TPP Ch 29 (n 23).

111 CMS annulment (n 103) [146]-[147].
} 
compensation for any circumstances at all. ${ }^{112}$ These materials show deep disagreement on everything -- role of circumstances precluding wrongfulness in the structure of State responsibility, relevant policy considerations, and technical black print - therefore clear and unqualified statements on the issue should be treated carefully.

Another way of approaching the issue would be to leave aside the cross-cutting rule of Article 27(b), and consider instead the weight of practice and authority in relation to each separate rule. Even though (in a regrettably lawyerly fashion) 'arguably', 'possibly', and 'likely' should be added to everything that follows, this way of posing the question may deliver somewhat clearer answers. No compensation is due when valid consent applies, unless the consent itself provides for it. The traditional law reflected in the Russian Indemnities, ${ }^{113}$ most of the ILC's materials ${ }^{114}$ and all comments by States, and the manner in which modern decisions have approached the issue support this view. No compensation is due for countermeasures either. The modern law (as reflected in the Air Services Agreement award), ${ }^{115}$ all the ILC's materials and comments by States, and the assumptions underlying the Mexican soft drinks decisions, support this view. Suggestions to the contrary ${ }^{116}$ appear to conflate non-opposability of countermeasures to third parties, which calls for reparation for (what is in their regard) a wrongful act, with compensation for applicable countermeasures (or applicability of countermeasures to some but not all of the multi-sourced equivalent obligations breached ${ }^{117}$ ). On necessity, authorities are divided: some States, the first reading of the ILC Articles, and the Fifth Special Rapporteur support compensation of material loss; other States appeared to object to compensation for precluded wrongfulness in all cases, including necessity. ${ }^{118}$ It is tempting to suggest that the greater weight of authority supports compensation for necessity, but this temptation is best resisted, in light of thinness of this practice.

If 'compensation for any material loss' is due, most likely for necessity, how would investment law handle that? The most intuitively plausible response is that it would be odd -

\footnotetext{
${ }^{112}$ M Forteau, 'Reparation in the Event of a Circumstance Precluding Wrongfulness' in J Crawford, A Pellet and S Olleson (eds), The Law of International Responsibility (OUP 2010); Crawford State Responsibility (n 9) 318-20.

113 Russian Indemnities (Russia/Turkey) (1912) 11 RIIA 421, 446; Crawford State Responsibility (n 9) 285.

114 A possible exception is Article 35 of the 1996 ILC Articles (first reading), which applies the 'does not prejudge' language to consent, but the commentary appears to have in mind the cases where the particular expression of consent itself requires assumption of risks, <http://legal.un.org/ilc/texts/instruments/english/commentaries/9_6_1996.pdf> Article 35 Commentary 2.

115 The Tribunal found that the US had properly applied a countermeasure, and did not suggest that compensation was called for, Air Service Agreement (n 72) [72]-[99]. The weight of this authority is limited since parties only asked the Tribunal to decide whether 'the US ha[d] the right to undertake such action as it undertook', and did not put forward claims about reparations, ibid 418-9.

116 The point is sometimes expressed as relating to countermeasures and sometimes to distress, Lowe (n 8) 410-11; Forteau (n 112) 893; Crawford State Responsibility (n 9) 318-9.

117 T Broude and Y Shany (eds), Multi-Sourced Equivalent Norms in International Law (Hart 2011).

118 Crawford State Responsibility (n 9) 318-9
} 
even nonsensical - for circumstances precluding wrongfulness to be admissible in principle and not affect compensation, in a regime that mainly revolves around compensation. If that is what the law says, then Ockham's razor yielded by an impatient purist's hand could slice away the admissibility of circumstances precluding wrongfulness in investment law in the first place, ${ }^{119}$ to avoid meaningless litigation. At the same time, a successful invocation of a circumstance precluding wrongfulness could make a practical difference, in terms of both international and domestic law. Domestic law of the home State may draw certain consequences from unlawful mistreatment of investors abroad, ${ }^{120}$ and officials and politicians in the host State may be required to take international law into account. ${ }^{121}$ Depending on the drafting and application, invocation of circumstances precluding wrongfulness to affect the characterisation of unlawfulness could have effect through the modicum of domestic law and practice.

Even if compensation is due as a matter of international law, the inference from the formulation of Article 27(b) is that neither restitution could be asked for, whether by the investor or its home State, nor cessation of conduct itself; a point of possible relevance for the indication of provisional measures. A more practical effect from circumstances precluding wrongfulness could follow from synchronisation with the practice of sovereign debt borrowing. If compensation is to be paid only after the necessity ceases to apply, ${ }^{122}$ and if the end of crisis is (eventually) reflected in more favourable ratings and conditions of borrowing, then the State could perhaps be able to borrow at a rate more favourable than during the crisis. Finally, 'compensation for any material loss' could be something different than 'compensation' in Article 36. It might exclude compensation for moral damage; affect calculation of interest; and could build upon, with all due caution, on compensation for lawful conduct in primary rules. ${ }^{123}$ Vagueness of the directly relevant rules may also permit a broader look for inspiration in other rules and regimes. Some of the relevant consideration could be procedural, e.g. whether the State has negotiated about compensation in good faith; ${ }^{124}$ others substantive, e.g. whether the relative importance of various interests justifies awarding less than full compensation. ${ }^{125}$ Overall, while one would be hard pushed to say with certainty what the positive international law on the

\footnotetext{
1192001 ILC Articles (n 1) arts 25(2)(a), 55.

${ }^{120}$ E.g. the US practice during the Cold War, N Maurer, The Empire Trap (Princeton University Press 2013) Ch 8.

${ }^{121}$ F Berman, 'International Law and the Ministerial Code' Guardian (25 October 2015).

122 A point that follows from Article 27 in a manner less obvious than the EDF annulment committee suggested, (n 99) [323], [330].

123 S Ripinsky and K Williams, Damages in International Investment Law (BIICL 2008) 339-52; B Sabahi, Compensation and Restitution in Investor-State Arbitration: Principles and Practice (OUP 2011) 179-80; cf A Boyle, 'Liability for Injurious Consequences of Acts not Prohibited by International Law' in J Crawford, A Pellet and S Olleson (eds), The Law of International Responsibility (OUP 2010).

1242001 ILC Articles with Commentaries (n 66) Article 27 Commentary 6.

125 Cf. 2001 ILC Articles (n 1) art 39; App. No 71243/01, Vistinš and Perepjolkins v Latvia , [GC] ECHR Judgment 25 October 2012 [112]-[113].
} 
calculation of compensation is, discussions in and around investment law have identified sensible legal and policy considerations that could be taken into account, and plausible directions in which law could develop. Against the backdrop of scarcity of practice more generally, that is not insignificant.

\section{Conclusion}

Unsurprisingly, application of circumstances precluding wrongfulness in international investment law has raised various issues that do not easily come together into a coherent argument. Possibly relevant practice on consent, upon closer examination, reveals itself to be related to sources and content of primary obligations, rather than secondary rules, or turn on broader questions of structure and purpose of international investment law. Self-defence provides an interesting perspective for a discussion of interaction between various primary regimes, even if its relevance as a circumstance precluding wrongfulness in international investment law is not immediately obvious. Countermeasures have been explicitly invoked and dealt with in investment dispute settlement, exploring the tension between inter- and investor-State elements in international investment law. The majority position in NAFTA soft drinks decisions, refusing to oppose interState countermeasures to international law right-holding investors, is persuasive in blackletter terms. Its sweeping implications may come under critical scrutiny if applied to international trade law and third-party countermeasures. Developments regarding necessity are the hardest to assess. The point made in this article is that despite appearances to the contrary, the corpus of Argentinean decisions has contributed almost nothing to international (investment) law, and the journey of exploration has been so disappointing as to nudge the practice on the issue decisively away from necessity. Finally, on the important cross-cutting issue of compensation for successful invocation of circumstances precluding wrongfulness, consensus in law of State responsibility is very thin indeed. Against that low starting point, the practice of investment law has provided identified possibly relevant considerations.

There are three ways in which the systemic implications of this state of affairs may be read. Perhaps there is nothing unusual or interesting about this story: this is simply how international law works. Treaty and arbitral practice on circumstances precluding wrongfulness demonstrate the messy reality of making and development of international law, drawing in its delightfully decentralised manner upon various sources, categories, regimes, and institutions, all mixed together by tactical considerations of particular disputing parties. Secondly, the practice of investment law may be following the sweeping historical narrative (sketched in Section II), with 
important issues increasingly expressed outside the rubric. For example, once the systemic importance of clear and nuanced rules on crises was appreciated, treaty and arbitral practice decisively shifted its attention away from necessity as a secondary rule, instead articulating concerns in terms of primary obligations and exceptions, and procedural qualifications. That is a perfectly sensible way for law to develop. The final point relates to the category of circumstances precluding wrongfulness as such. Elaboration of individual circumstances by the ILC is to be welcomed. ${ }^{126}$ But it is less obvious that expressing them in a single category has been equally successful. The rules on termination of treaties, closely if somewhat uncertainly related to circumstances precluding wrongfulness, ${ }^{127}$ provide an example of another category that encompasses substantively varied rules -- but one that is coherent in a broad functional sense, reflected in cross-cutting procedural rules. ${ }^{128}$ Practice in investment law shows little comparable systemic coherence, either regarding individual circumstances or cross-cutting rules. Indeed, the choice to draft general rules (such as on compensation) may have nudged the developments away from attention to peculiarities of individual rules, and in the direction of a search for crosscutting answers. It is not at all clear that the rubric can contain such a discussion and provide such answers. ${ }^{129}$ It remains to be seen whether sceptics will be assuaged by future developments. But, if decisions on necessity and countermeasures are anything to go by, these developments will be of great interest to both practitioners and academic commentators, and directly touch upon the systemic pulse of international investment law and law of State responsibility.

${ }^{126}$ Crawford State Responsibility (n 9) 280.

127 M Fitzmaurice, 'Exceptional Circumstances and Treaty Commitments' in D Hollis (ed), The Oxford Guide to Treaties (OUP 2012).

${ }^{128}$ L Helfer, 'Terminating Treaties' ibid.

${ }^{129}$ Lowe (n 8). 